H.t?

$+3$

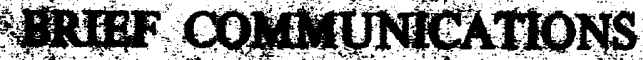

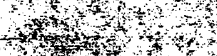

$4+3 w^{2}$

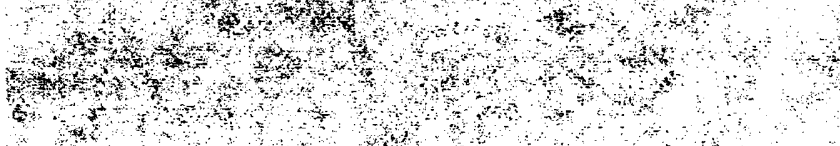

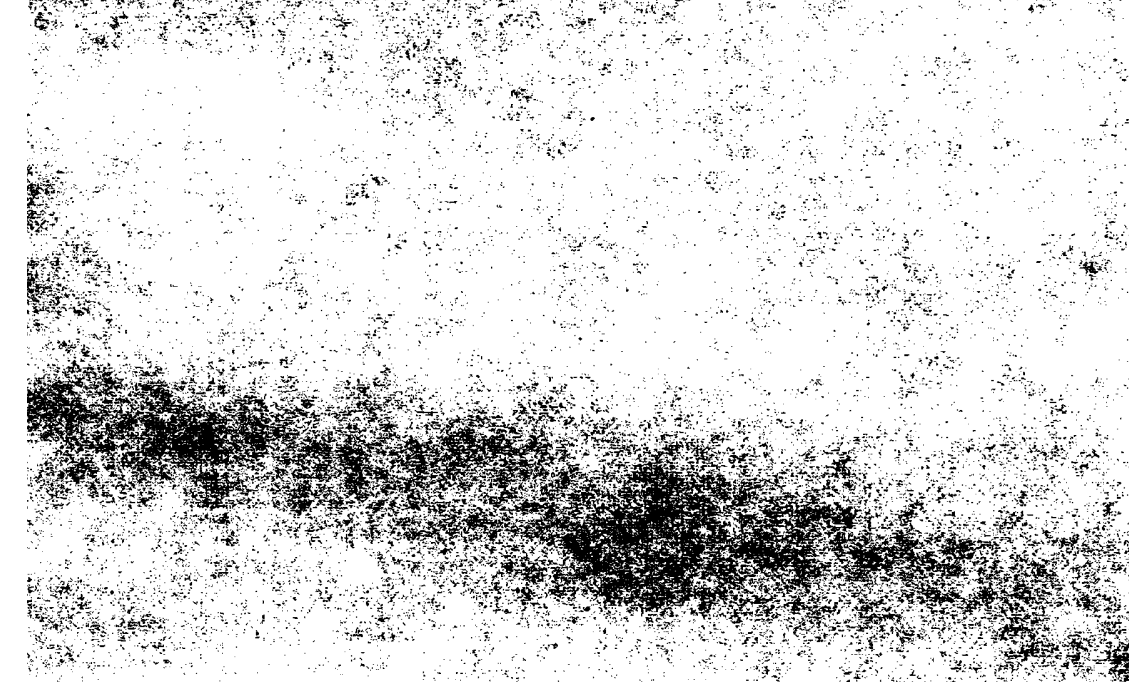

\section{s.}

HW

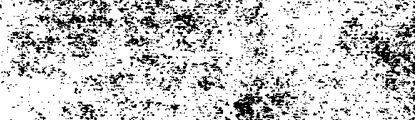

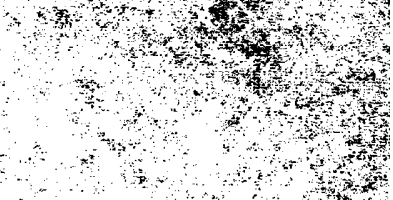

$y^{4}+4$

\section{(1)}

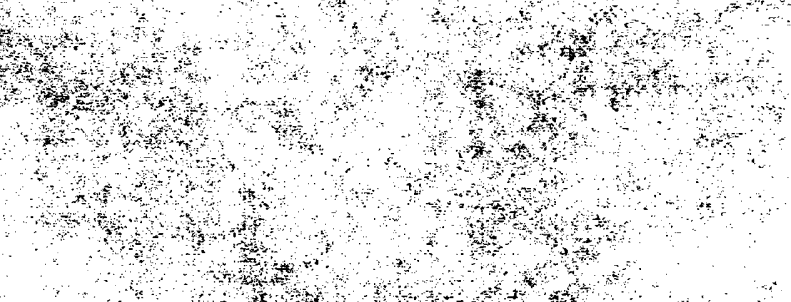

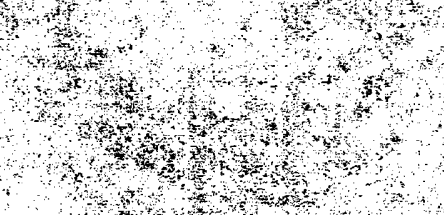$$
\text { . }
$$ 


\title{
Inhibin-like activity of bovine ovarian extracts in male and female rats
}

\author{
C. R. N. Hopkinson, E. Daume, G. Sturm, E. Fritze, S. Kaiser and \\ C. Hirschhäuser* \\ Department of Obstetrics and Gynaecology, University of Marburg, 355 Marburg, West Germany, \\ and ${ }^{*}$ Department of Urology, City Hospital, Solingen, West Germany
}

Several recent reports have confirmed the original postulate of McCullagh (1932) that the testis secretes a non-steroidal hormone which selectively inhibits pituitary FSH secretion. For example, extracts of bovine testis depress FSH levels in castrated male sheep (Lee, Keogh, de Kretser \& Hudson, 1974) and FSH secretion in male rats is inhibited by human and bull seminal plasma (Franchimont, 1972; Franchimont, Chari, Hagelstein \& Duraiswami, 1975). Inhibin activity has also been demonstrated in rete testis fluid (Setchell \& Sirinathsinghji, 1972; Setchell \& Jacks, 1974). Prompted in part by the fact that no known hormone is confined exclusively to one sex, we decided to test bovine ovarian extracts for inhibin-like activity. A preliminary account of this work has appeared (Hopkinson, Sturm, Daume, Fritze \& Hirschhäuser, 1975).

Two test systems were employed: the effect of injection of extracts on testicular compensatory hypertrophy in rats after hemicastration and on serum FSH levels in castrated male and female rats. Testicular extracts of bulls and rats were used as positive controls and bovine serum albumin (BSA), bovine gamma globulin (BGG) and bovine kidney extract as negative controls.

\section{Methods and results}

Extracts. Bovine ovaries, testes and kidneys and rat testes were obtained within $1 \mathrm{~h}$ of death and placed on ice. Ovaries were frozen, sectioned, left overnight at $4^{\circ} \mathrm{C}$ and the tissue fluid (mostly follicular) collected. After cutting the tunica, bovine testes were placed in a desiccator and left overnight under vacuum at $4^{\circ} \mathrm{C}$ : approximately $25 \mathrm{ml}$ tissue fluid containing $55 \mathrm{mg}$ protein $/ \mathrm{ml} \mathrm{per} 100 \mathrm{~g}$ testes was recovered from the bottom of the desiccator. Bovine kidneys and rat testes were homogenized in $0.85 \%(\mathrm{w} / \mathrm{v}) \mathrm{NaCl}$, centrifuged at $40,000 \mathrm{~g}$ for $1 \mathrm{~h}$ and the supernatant harvested. All extracts were extracted eight times with 6 volumes diethyl ether, except for the dialysis experiment for which ovarian fluid was dialysed overnight against acetate buffer, $\mathrm{pH} 5.5$, containing $1 \%$ BSA. Extracts were then freeze dried and the residue dissolved in $0.85 \%(\mathrm{w} / \mathrm{v}) \mathrm{NaCl}$. A sample $(500 \mathrm{mg})$ of the ether-extracted ovarian fluid residue was incubated at $\mathrm{pH} 7.8$ for $2 \mathrm{~h}$ with $15 \mathrm{mg}$ trypsin at $37^{\circ} \mathrm{C}$. The concentrations of the extracts were adjusted with $0.85 \%$ saline so that $0.3 \mathrm{ml}$ contained the desired quantity of material for one injection.

Animals. Sprague-Dawley rats were used which weighed $220-250 \mathrm{~g}$ for assessing the effects of dialysis and $320-350 \mathrm{~g}$ for the other experiments. Unilateral and bilateral gonadectomy of male and female rats were performed under ether anaesthesia. Castrated male rats received a single daily s.c. injection of 20 or $120 \mu \mathrm{g}$ dihydrotestosterone in arachis oil $/ 100 \mathrm{~g}$ body weight/day in addition to the tissue extracts. Previous work (unpublished) indicated that androgen treatment of such animals increased the sensitivity of the test system.

Assays. Plasma FSH was measured as previously described (Griffiths, Hooper \& Hopkinson, 1975) and ovarian extract in a final concentration of $2 \mathrm{mg} / \mathrm{ml}$ did not interfere with the assay. All samples from a single experiment were estimated in one assay and the mean intra-assay variation was $5.4 \%$. Androgens were measured in rat plasma by a procedure similar to that used for human plasma (Hirschhäuser, Hopkinson, Sturm \& Coert, 1975). The use of a tris buffer, $\mathrm{pH} 8.5$, as diluent resulted in greater sensitivity. The volume of plasma extracted varied from 20 to $100 \mu \mathrm{l}$ and androgens were measured against a testosterone standard. The mean intra-assay coefficient of variation was $8 \%$ at a concentration of $100 \mathrm{pg} /$ tube, $n=10$. 
Residual oestradiol-17 $\beta$ in the ovarian extract was measured by radioimmunoassay essentially as described by de Jong, Hey \& van der Molen (1973). Approximately $2500 \mathrm{~d} / \mathrm{min}\left[{ }^{3} \mathrm{H}\right]$ oestradiol (sp. act. $110 \mathrm{Ci} / \mathrm{mmol}$ ) was added to $300 \mathrm{mg}$ ovarian extract dissolved in $3 \mathrm{ml} \mathrm{saline}$. This was extracted with $10 \mathrm{ml}$ ether and after evaporation to dryness the residue was taken up in $0.3 \mathrm{ml}$ benzene/ methanol $(85: 15 \mathrm{v} / \mathrm{v})$. This was applied to a $15-\mathrm{cm}$ Sephadex LH20 column. The column was eluted with solvent, the appropriate fraction collected, evaporated to dryness and taken up in $1.0 \mathrm{ml}$ PBS, pH 7.5, containing $0.1 \%$ gelatine (PBS-gel). Aliquots $(2 \times 100 \mu \mathrm{l}$ and $2 \times 50 \mu \mathrm{l})$ were pipetted into small glass tubes for assay, $400 \mu \mathrm{l}$ being taken for counting to estimate recovery. A blank was prepared by a procedure identical to that described above except that water was substituted for ovarian extract. Standards from 0 to $200 \mathrm{pg}$ in $100 \mu \mathrm{l}$ PBS-gel were pipetted into the tubes and all tubes received $50 \mu \mathrm{l} 2 \%$ bovine gamma globulin followed by $100 \mu$ l anti-oestradiol serum (Exley, Johnson \& Dean, 1971) diluted 1:30,000 in PBS-gel. After mixing, the tubes were left for $30 \mathrm{~min}$ at $20^{\circ} \mathrm{C}$. Tritiated oestradiol $(6000 \mathrm{ct} / \mathrm{min})$ was then added in $100 \mu \mathrm{l}$ PBS-gel and the tubes left overnight at $4^{\circ} \mathrm{C}$. Bound hormone was separated from free by the dextran-coated charcoal method and the bound radioactivity counted. Blanks were virtually zero $(<5 \mathrm{pg})$. The mean $( \pm$ S.D. ) oestradiol content of the treated ovarian extract was found to be $465 \pm 60 \mathrm{pg} / 100 \mathrm{mg}$ ovarian extract $(n=4)$. Mean recovery was $63 \%$ and the coefficient of variation was $8 \%$ at a level of $500 \mathrm{pg}$ per sample.

When saline or kidney extract were injected twice daily for 14 days commencing on the day after hemicastration, the mean \pm S.D. $(N=5)$ difference between the weights of the testes was $387 \pm 122$ $\mathrm{mg}$ and $440 \pm 150 \mathrm{mg}$ respectively. The values for twice daily injections of $50 \mathrm{mg}$ ovarian and rat and bull testicular extracts were $30 \pm 77,80 \pm 160$ and $80 \pm 128 \mathrm{mg}$ respectively, and were significantly different $(P<0.05)$. Some loss of body weight occurred with the extract treatments, but this was significant $(P<0.05)$ only for the latter. In 10 similarly bilaterally castrated rats the mean within-pair weight difference was $6.4 \%$, the maximum being $9 \%$.

Table 1. The effects (mean \pm S.D.) of twice daily injections of tissue extracts on FSH concentrations in gonadectomized rats

\begin{tabular}{clccc}
\hline Rats & \multicolumn{1}{c}{ Treatment } & No. of rats & FSH (ng/ml) \\
\hline Males (a) & (1) $25 \mathrm{mg}$ ovarian extract & 5 & $386 \pm 47$ \\
& (2) 25 mg tryptic digest of ovarian extract & 5 & $500 \pm 44$ \\
& (3) $25 \mathrm{mg} \mathrm{BSA}$ & 5 & $551 \pm 148$ \\
& (4) $100 \mathrm{mg}$ ovarian extract & 5 & $203 \pm 60$ \\
& (5) $100 \mathrm{mg}$ kidney extract & 5 & $453 \pm 100$ \\
(b) & (6) $50 \mathrm{mg}$ ovarian extract & 6 & $1475 \pm 191$ \\
& (7) $50 \mathrm{mg}$ dialysed ovarian extract & 6 & $1315 \pm 145$ \\
Females & (8) $50 \mathrm{mg}$ BGG & 6 & $1996 \pm 306$ \\
& (9) $100 \mathrm{mg}$ ovarian extract & 5 & $766 \pm 68.7$ \\
& (10) $100 \mathrm{mg}$ kidney extract & 5 & $990 \pm 186$ \\
\hline
\end{tabular}

Animals were injected for 2 days starting the day after surgery and were then bled on the 3rd day, about $12 \mathrm{~h}$ after the last injection. Castrated male rats received, in addition to tissue extracts, (a) $120 \mu \mathrm{g}$ or (b) $20 \mu \mathrm{g}$ dihydrotestosterone $/ 100 \mathrm{~g}$ body weight each day given as a single s.c. injection in arachis oil. Female rats were not treated with steroids.

The significance of differences between means (Student's $t$ test) was: 1 versus $2, P<0.01$; 1 versus $3, P<0.05 ; 1$ versus $4, P<0.01 ; 4$ versus $5, P<0.01 ; 6$ versus $8, P<0.01 ; 7$ versus 8 , $P<0.01 ; 9$ versus $10, P<0.05$.

The effects of ovarian extracts on serum FSH levels are shown in Table 1. In castrated male rats 25 or $100 \mathrm{mg}$ ovarian extract significantly depressed FSH levels when compared to $25 \mathrm{mg} \mathrm{BSA}(P<$ $0.05)$ or $100 \mathrm{mg}$ kidney extract $(P<0.01)$, and $100 \mathrm{mg}$ ovarian extract were significantly $(P<0.01)$ more effective than $25 \mathrm{mg}$, showing that the response was dose dependent. Inhibin-like activity was destroyed by trypsin incubation. A significant $(P<0.05)$ depression in FSH levels in female rats was also obtained by injecting $100 \mathrm{mg}$ ovarian extract. Ovarian fluid samples subjected to ether extraction or dialysis had similar activity.

The possibility that the tissue extracts were altering the clearance rate of the injected steroid, thus producing an artefact, was checked by estimating the plasma androgen concentration at two different 
times after injection of $200 \mu \mathrm{g}$ dihydrotestosterone into 12 castrated male rats, 6 of which had been injected with $50 \mathrm{mg}$ ovarian extract twice daily for 2 days, the other 6 with saline. Blood samples were taken 7.5 and $28 \mathrm{~h}$ after injection and the mean ( \pm S.D.) plasma androgen levels $(\mathrm{ng} / \mathrm{ml})$ were $1 \cdot 2 \pm$ 0.50 and $0.40 \pm 0.14$ respectively for the saline-injected animals, and $1.3 \pm 0.40$ and $0.34 \pm 0.08$ for the extract-injected animals. The results in Table 1 do not therefore appear to be due to altered steroid availability.

\section{Discussion}

Compensatory hypertrophy after unilateral castration was used as one of the test systems. In controls, an increase of approximately $30 \%$ in the weight of the remaining testis was observed in 14 days. The literature is confused about the effects of unilateral castration on the weight of the remaining testis in rats (see Setchell \& Waites, 1972). Changes ranging from non-significant to a $50 \%$ increase 21 days after operation have been reported. We have no explanation for the discrepancy. The rats used for the unilateral castration experiments reported here were however much heavier at the time of operation than those of Setchell \& Waites (1972).

Our results suggest that ovaries, like testes, might contain non-steroidal inhibitors of FSH secretion. The FSH inhibition produced by ovarian fluid was not due to its content of oestradiol-17 $\beta$ as this was shown to be very low after ether extraction. In similarly castrated male rats the minimum daily dose of oestradiol-17 $\beta$ monobenzoate (more effective than the free steroid) which produced a significant decrease in serum FSH was $1 \mu \mathrm{g}$ /day, i.e. 1000 times that associated with our highest extract dose. Although other steroids were not estimated, we consider it most unlikely that sufficient quantities of any steroid remained after ether extraction to produce the observed effects.

Although body weight loss seen in the hemicastration experiment did suggest the presence of some non-specific effects, these were more marked for the testicular than ovarian extracts and all the radioimmunoassay results were assessed relative to animals which had received kidney extract, BSA or BGG, the latter being major constituents of bovine plasma. Tryptic digestion destroyed the activity suggesting that a protein or peptide is responsible for the observed effects. Dialysis did not affect activity, indicating that the molecule is too large to pass through the membrane or that a small peptide bound to a larger protein (see Kent, 1975) is responsible.

Bovine ovarian tissue therefore appears to contain a non-steroidal inhibitor of FSH secretion. It is, of course, tempting to speculate that such a substance might be analogous to inhibin which is believed to control FSH regulation in the male. Although we have as yet no direct evidence to substantiate this speculation, the recent demonstration that antibodies against a bovine seminal plasma extract were capable of elevating FSH levels in female as well as in male rats (Franchimont et al., 1975) suggests that non-steroidal factors are important in the regulation of gonadotrophin secretion in the female. Our results strongly suggest an ovarian source for such factors.

The physiological importance of this factor is as yet unknown, but there are some observations in the literature which could be explained by the concept of an 'ovarian inhibin', though other possible explanations remain. The increase in FSH sometimes seen before the human menopause while LH remains normal could be due to a lack of inhibin (Korenman \& Sherman, 1976). Bast \& Greenwald (1974) have reported elevated FSH but not LH levels in lactating hamsters which had atretic ovarian follicles. Further work is necessary to clarify the nature and significance of non-steroidal gonadotrophin inhibitors in male and female.

We thank the Deutsche Forschungsgemeinschaft (Grant Hi 203/3-4) for financial support; and NIAMDD, NIH, Bethesda, USA for radioimmunoassay materials.

\section{References}

BAST, J.D. \& Greenwald, G.S. (1974) Daily concentrations of gonadotrophins and prolactin in the serum of pregnant or lactating hamsters. J. Endocr. 63, 527-532. 
DE JONG, F.H., HeY, A.H. \& VAN deR MOlen, H.J. (1973) Effect of gonadotrophins on the secretion of oestradiol-17 $\beta$ and testosterone by the rat testis. J. Endocr. 57, 277-284.

EXLEY, D., JoHnson, M.W. \& DEAN P.G.D. (1971) Antisera highly specific for $17 \beta$-oestradiol. Steroids 18, 605-623.

Franchimont, P. (1972) Human gonadotrophin secretion. J. R. Coll. Physicians, Lond. 6, 283-298.

Franchimont, P., Chari, S., Hagelstein, M. \& Duraiswami, S. (1975) Existence of follicle-stimulating hormone inhibiting factor 'inhibin' in bull seminal plasma. Nature, Lond. 257, 402-404.

Griffiths, E.C., Hooper, K.C. \& Hopkinson, C.R.N. (1975) Further studies on enzymic inactivation of luteinizing hormone-releasing hormone (LH-RH) by peptidase in the rat hypothalamus. Acta endocr., Copenh. 79, 7-15.

HirschHäuser, C., Hopkinson, C.R.N., Sturm, G. \& COERT, A. (1975) Testosterone undecanoate: a new orally active androgen. Acta endocr., Copenh. 80, 179-187.

Hopkinson, C.R.N., Sturm, G., Daume, E., Fritze, E. \& HirschHÄuser, C. (1975) Non-steroidal inhibition of FSH secretion by bovine ovarian fuid in male and female rats. Int. Res. Commun. Syst. $3,588$.

KENT, H.A., JR (1975) Contraceptive polypeptide from hamster zygotes: sequence of amino acids in the compound. Biol. Reprod. 12, 504-507.

Korenman, S.G. \& Sherman, B.M. (1976) The Endoctine Function of the Human Ovary, pp. 359-372. Academic Press, New York.

LEe, V.W.K., KeOGH, E.J., dE KRETSER, D.M. \& Hudson, B. (1974) Selective suppression of FSH by testis extracts. Int. Res. Commun. Syst. 2, 1406.

McCullagh, D.R. (1932) Dual endocrine activity of the testis. Science, N.Y. 76, 19-20.

Setchell, B.P. \& JACKS, F. (1974) Inhibin-like activity in rete testis fluid. J. Endocr. 62, 675-6.

Setchell, B.P. \& SirinathsinghJi, D.J. (1972) Antigonadotrophic activity in rete testis fluid, a possible “inhibin". J. Endocr. 53, lx-1xi.

Setchell, B.P. \& Waites, G.M.H. (1972) The effect of local heating of the testis on the flow and composition of rete testis fluid in the rat, with some observations on the effects of age and unilateral castration. J. Reprod. Fert. 30, 225-233.

Received 21 July 1976 